\title{
STUDIES ON THE CAVERNICOLE PTOMAPHAGUS OF THE UNITED STATES (COLEOPTERA: CATOPIDAE $)^{1}$
}

\author{
By Thomas C. Barr, Jr. \\ Department of Zoology, University of Kentucky
}

The cave beetles of the United States include members of the families Carabidae, Staphylinidae, Pselaphidae, Catopidae (=Leptodiridae), and occasionally Brathinidae, Tenebrionidae, Cryptophagidae, and Dermestidae. Troglobite species (obligate cavernicoles) are found among the carabids (Trechini, Agonini), pselaphids (Batrisini, Bythinini, and Speleobamini), and catopids (Ptomaphagini). In comparison with the cave carabids and cave pselaphids, which have been the objects of recent and continuing studies by American authors (see Barr I960a for bibliography of cave trechines, Barr I960b on agonine cave carabids, and Park 1960 on cave pselaphids), the cave catopids have received less attention. The most recent paper treating all known species of U.S. cave catopids is that of Jeannel (1949).

Although the essentially European subfamily Bathysciinae includes numerous highly modified troglobitic species, catopids in U.S. caves are represented only by a few members of the genus Ptomaphagus Illiger and rarely on occasional Catops or Nemadus. All U. S. species of Ptomaphagus, epigean or cavernicole, belong to the subgenus Adelops Tellkampf (type species: Adelops hirtus Tellkampf i844, from Mammoth Cave, Kentucky). Twelve epigean species, 2 troglophile species, and 7 troglobitic species of Adelops have been described from the United States, and 3 more troglobitic species are described in the present paper. The cavernicole species thus comprise half of the number of species known at the present time. These inhabit caves of Missouri, Oklahoma, Arkansas, Iowa, Illinois, Kentucky, Tennessee, Alabama, and Georgia. Seven species of the cavernicola group are clustered in northeastern Alabama and adjacent parts of Tennessee and Georgia, but otherwise, the cave species are distinctly allopatric, indigenous to cave systems widely separated from each other, either by non-caverniferous regions or cave areas where Adelops has not been discovered.

Acknowledgments: - I wish to thank the following for contribution of specimens: Oscar Hawksley, Leslie Hubricht, Bro. G. Nicho-

\footnotetext{
${ }^{1}$ This investigation was supported by a grant (G-18765) from the National Science Foundation.

Manuscript received by the editor July 25, 1962.
} 
las, F.S.C., R. Oesch, Stewart Peck, Jack Reynolds, M. W. Sanderson, and H. R. Steeves, Jr. For assistance in collecting, I am indebted to Oscar Hawksley, Leslie Hubricht, Walter B. Jones, H. R. Steeves, Jr., and Frederick R. Whitesell. Dr. René Jeannel, Museum National d'Histoire Naturelle, Paris, kindly lent me the type of $P$. laticornis for examination.

Key to known Species of Cavernicole Ptomaphagus of the United States (Based on Jeannel 1949)

I Elytral apex rounded in the male, obliquely truncate with external apical angle present in the female; pronotum with feeble or no transverse strigae (hirtus group) …….......... 2

$I^{\prime} \quad$ Elytral apex rounded or truncate in the male, acuminate in the female, external apical angle effaced; pronotum usually with prominent transverse strigae (cavernicola group) .... 4

2( I) Eyes reduced to a very small, pale areola; pronotal disc without transverse strigation or with strigae limited to region near the margins

$2^{\prime} \quad$ Eyes small but pigmented; pronotal disc lightly and irregularly transversely strigose; Oklahoma, Arkansas

shapardi Sanderson

3(2) Antennal segment VIII half as long as wide; transverse strigae feebly developed near margins of pronotal disc; southern Illinois nicholasi $\mathrm{n}$. sp.

$3^{\prime} \quad$ Antennal segment VIII three-fourths as long as wide; transverse strigae almost completely absent from pronotal disc; west-central Kentucky .............................. hirtus Tellkampf

4( I ) Eyes reduced to a very small, pale areola, their diameter less than distance from anterior margin of eye to base of antenna; no functional wings; Alabama, Tennessee, or Georgia ..... 5

$4^{\prime} \quad$ Eyes large and pigmented, their diameter greater than the distance from anterior margin of eye to base of antenna; functional wings present; Ozark region

cavernicola Schwarz

5(4) Antennal segment III not longer than segment II ...........6 6

$5^{\prime} \quad$ Antennal segment III longer than segment II ................ IO

6(5) Form oblong, less convex; pronotum narrow, its greatest

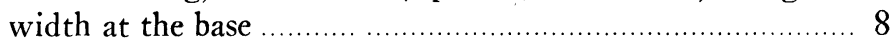

$6^{\prime} \quad$ Form shorter and convex; pronotum broad, its greatest width in front of the hind angles; elytra short and convex, briefly attenuate in the male; antennal segments IX and $X$ not longer than wide 
7(6) Transverse strigae of pronotum regular and distinct; antennae slender, reaching to anterior third of elytra when laid back; elytral apex evenly rounded in the male; Grundy and Franklin counties, Tennessee, to north-central Jackson Co., Alabama .................................................. hatchi Jeannel

$7^{\prime} \quad$ Transverse strigae of pronotum irregular and dissociated, rather superficial; antennae thicker, reaching only to base of pronotum when laid back; elytral apex angular in male; Dade Co., Georgia whiteselli $\mathrm{n}$. sp.

8(6) Antenna longer, easily reaching beyond base of pronotum; $\mathrm{V}$, VI, and VII slender, VIII small but not transverse, almost as wide as long

$8^{\prime} \quad$ Antenna shorter, scarcely reaching the base of the pronotum; $\mathrm{V}$ and VI dilated, VII greatly enlarged, VIII very transverse (twice as wide as long); Madison Co., Alabama

laticornis Jeannel

9(8) Color reddish-brown; body robust; VII and VIII enlarged; posterior pronotal angles relatively blunt; DeKalb and Wilson counties, Tennessee hubrichti Barr

$9^{\prime} \quad$ Color pale testaceous or rufotestaceous; body slender; VII and VIII not appreciably enlarged; posterior pronotal angles sharper; northeast Alabama ........................ henroti Jeannel

Io(5) Size larger $(2.8-3.5 \mathrm{~mm})$; pronotum distinctly wider, the transverse strigae fine but distinct; elytral strigae very fine and superficial

IO Size small $(2.2-2.5 \mathrm{~mm})$; pronotum narrower, with transverse strigae superficial and dissociated on the disc; elytral strigae deeper and more distinct; northeast Alabama

valentinei Jeannel

II (IO) Elytral apices subtruncate in the male; northeast Alabama loedingi Hatch

I I' Elytral apices rounded in the male; Franklin Co., Tennessee fecundus $\mathrm{n}$. $\mathrm{sp}$.

The above key is a tentative one, since there are probably several undescribed species of Ptomaphagus which occur in the caves of the United States. Most of these will be species which have pigmented eyes, will be most abundant in the twilight zone, and will key out near $P$. cavernicola. I have seen scattered material of this nature from caves in Florida, Texas, and Alabama.

\section{hirtus group}

Elytral apex rounded in the male, obliquely truncate in the female; transverse strigation of pronotal disc greatly reduced in some species. 


\section{Ptomaphagus (Adelops) hirtus Tellkampf}

Adelops hirtus Tellkampf 1844: 313, fig. 106; type: Mammoth Cave, Kentucky. Hatch 1928: 169; 1933: 208. Jeannel 1931: 408.

Ptomaphagus (Adelops) hirtus: Jeannel 1936: 93, figs. 154-155; 1949: 99. Barr 1962: 282.

Common in Mammoth Cave, Kentucky, and known from caves in Hardin, Hart, Edmonson, Barren, and Warren counties, Kentucky, along the western Pennyroyal plateau and Dripping Springs escarpment. Troglobite.

Ptomaphagus (Adelops) shapardi Sanderson

Sanderson 1939: 121; type: Dresser Cave, Cherokee Co., Oklahoma (in coll. Illinois Nat. Hist. Surv. Div., Urbana). Jeannel 1949: 101.

Described from Dresser Cave, 5 miles north of Fort Gibson, Oklahoma, and reported from northwestern Arkansas (Sanderson, pers. comm.). The pronotal disc is transversely strigose, although less so than in most members of the cavernicola group, to which it was assigned by Jeannel (1949). In the sexual dimorphism of the elytral apex and in general form it seems closer to hirtus (and to the montane species $P$. mitchellensis Hatch, as suggested by Sanderson in the original description of $P$. shapardi). Small, pigmented eyes are present, the individual facets distinct. Troglophile?

Ptomaphagus (Adelops) nicholasi n. sp.

Length 2.3-2.7 mm; width I.3-I.4 mm. Color dark brown to pale yellow testaceous. Form oblong, very convex, narrowing posteriorly. Eyes reduced to a small, pale areola. Antenna slender and elongate, extending to the anterior third of the elytra when laid back; segments I, II, and III subequal; IV, V, and VI each half as long as III, subequal; VII subconical, its apical diameter equal to its length; VIII very transverse, twice as wide as long, slightly narrower than VII; IX and $X$ subquadrate and subequal; $X I$ three-fourths as wide as long and subequal in width to $X$, attenuate in apical three-eighths. Pronotum $2 / 3$ as long as wide, widest just before the base, slightly wider than elytra; hind angles a little less than right, acuminate; base entire, curved slightly back to the hind angles; disc with transverse strigae distinct only near the margins, strigae dissociated, indistinct, and very superficial medially. Elytra elongate, $3 / 4$ as wide as long, subparallel, gradually attenuate to the apices, twice as long as pronotum; elytral apices rounded in the male, obliquely truncate with external apical angle in the female; strigae oblique to the suture. Described on five specimens, the holotype male (American Museum of Natural History), allotype female $(\mathrm{AMNH})$, and three paratypes (coll. Barr), from Fogelpole Cave, Monroe Co., Illinois, 22 October 196I (Bro. G. Nicholas, F.S.C., leg.). 
This is the first troglobitic beetle to be described from the caves of southern Illinois. It seems most closely related, at least morphologically, to hirtus, from which it is readily distinguished by the transverse strigation at the margins of the pronotal disc and by the more transverse eighth antennal segment. The species is a morphological and geographic intermediate between hirtus and shapardi with respect to the pronotal strigation. The eyes, however, are very small and show no facets or pigmentation.

\section{cavernicola group}

Elytral apex either rounded or truncate in the male, acuminate in the female; transverse strigation of pronotal disc pronounced (except in valentinei Jeannel and whiteselli n. sp.).

\section{Ptomaphagus (Adelops) cavernicola Schwarz}

Schwarz 1898: 57; type: Marble (= Marvel) Cave, Stone Co., Missouri (U. S. Nat. Mus. \# 1424). Jeannel 1936: 92; 1949: 101.

The type of the species group has large, pigmented eyes and functional wings. It is apparently widely distributed in the Ozark region. My own material includes specimens from the following localities:

ARKANSAS. Washington Co.: Granny Dean Cave, near Black Oak. MISSOURI. Benton Co.: Flippen Cave, Lish Estes Cave, Luegenbeil Cave, Spring Cave. Boone Co.: Devils Icebox. Camden Co.: Carroll Cave. Dallas Co.: Cat Hollow Cave. Franklin Co.: Fisher Cave. Laclede Co. Mary Lawson Cave. Stone Co.: Marvel Cave (type loc.), Dillo Cave, Fairy Cave, Gentry Cave. IOWA. Jackson Co.: Hunter Cave, near Andrew.

In the caves, $P$. cavernicola is most abundant upon feces of bats or raccoons, or upon dead bat carcasses. Occasionally it occurs on wet, rotten wood. In Dillo Cave, Stone Co., Missouri, many larvae were collected from raccoon feces on 27 January 1958 , and the species possibly reproduces throughout the year. $P$. cavernicola appears to be more tolerant of moisture and temperature fluctuations than its eastern troglobite relatives. In Marvel Cave large numbers were secured from dead bats (Myotis grisescens Howell) in the Waterfall Room, January 1958. A cold, dry current of air, blowing from a passage leading to a newly opened artificial entrance, was flowing over the bat carcasses. Although the species is known only from caves, this tolerance, in conjunction with the well developed eyes and wings, the retention of some pigment, and the comparatively extensive geographic distribution indicate that it is a troglophile.

\section{Ptomaphagus (Adelops) hatchi Jeannel}

Jeannel 1933: 252; type: Wonder Cave, Grundy Co., Tennessee (in Mus. Nat. Hist. Nat., Paris). Jeannel 1936: 93; 1949: 101. 
Rather widely distributed in the caves of southeastern Grundy County (Crystal, Partin Spring, Trussell, Wonder) and eastern Franklin County (Crownover Saltpeter, Custard Hollow, Dry, Lost Cove, Wet, Ranie Willis), Tennessee, and in the caves of Crow Creek Valley in adjacent Jackson County, Alabama (Jesse Elliott, Talley Ditch). Troglobite.

Ptomaphagus (Adelops) whiteselli n. sp.

Length $2.8 \mathrm{~mm}$; width $\mathrm{I} .3 \mathrm{~mm}$. Color dark brown, testaceous. Form oblong, very convex, narrowing posteriorly. Eyes reduced to a small, pale areola. Antenna rather short and thickened, extending to the base of the pronotum only when laid back; segment I longer and wider than II and III, which are subequal; IV, V, and VI subequal, cylindrical, a little shorter than III, three-fifths as wide as long; VII two-fifths longer than VI, subconical, the apical width $5 / 7$ the length; VIII transverse, half as long as wide; IX and X subquadrate, $2 \mathrm{I} / 2$ times as long as VIII; XI four-fifths longer than X, attenuate in apical four-ninths. Pronotum subequal in width to elytra, widest just before the base, $3 / 5$ as long as wide; hind angles a little less than right, acuminate; base very shallowly emarginate medial to the hind angles; disc with transverse strigae superficial, irregular, and dissociated. Elytra elongate, subparallel, gradually attenuate to the apices, $2 \mathrm{I} / 2$ times as long as pronotum; apex briefly and obl quely subtruncate in the male (female unknown); strigae oblique to the suture. Described from a unique male, the holotype (American Museum of Natural History), Sittons Cave, Dade Co., Georgia, 20 March 1959 (T. C. Barr, Jr., leg.).

This is the first troglobitic beetle to be described from the caves of northwestern Georgia. In the short, thickened antennae the species resembles $P$. laticornis Jeannel, from which it differs in the more robust body and longer I I th antennal segment. Since $P$. whiteselli is known from a single male and $P$. laticornis from a single female, the two species may not be satisfactorily compared at the present time. $P$. whiteselli may be distinguished from $P$. hatchi, which it resembles in convex form and in having the greatest width of the pronotum in front of the hind angles, by the irregular, superficial strigation of the pronotal disc, by the thicker, shorter antennae, and by the elytral apices of the male, which are more briefly subtruncate and less rounded. The apex of the aedeagus is smaller and narrower than in hatchi. Named in honor of Dr. Frederick R. Whitesell, University of the South, Sewanee, Tennessee.

\section{Ptomaphagus (Adelops) laticornis Jeannel}

Jeannel 1949: 102; type: Scott Cave, Madison Co., Alabama (in Museum National d'Histoire Naturelle, Paris). 
Length $2.5 \mathrm{~mm}$. Testaceous. Similar in body proportions to $P$. henroti but with shorter, thicker antennae, the club somewhat flattened. Segments V and VI are thickened, VI less than twice as long as wide; VII very large, as in whiteselli; VIII short and very transverse, half as wide as long; IX and $X$ subquadrate; $X I$ two-sevenths longer than $X$, attenuate in apical one-fifth. Known only from the unique female type, which I have seen. Troglobite. Sympatric with P. henroti.

\section{Ptomaphagus (Adelops) henroti Jeannel}

Jeannel 1949: 102; type: Aladdin Cave, Madison Co., Alabama (in Museum National d'Histoire Naturelle, Paris).

The smallest and most slender of our troglobitic Adelops. Known from the type locality and nearby Scott Cave, Madison County, and from Horseshoe and Blowing Caves, Fannin Cove, in nearby Jackson County, Alabama. Jeannel (1949) described $P$. h. ellipticus as a distinct race from Shelta Cave, Huntsville, Madison County, but only two specimens are known. I have seen only nominate henroti.

\section{Ptomaphagus (Adelops) hubrichti Barr}

Barr 1958: 170; type: Cripps Mill Cave, DeKalb Co., Tennessee (in American Museum of Natural History, New York).

Common in caves of southern DeKalb County, at the eastern edge of the Central Basin in Tennessee, and more recently collected in Hayes Cave, near Statesville, in eastern Wilson County, Tennessee. Distinguished from henroti by the more robust body form, the dilated 7 th and 8 th antennal segments, and the blunter posterior pronotal angles. Troglobite.

\section{Ptomaphagus (Adelops) valentinei Jeannel}

Jeannel 1933: 252; type: Sauta Cave, near Lim Rock, Jackson Co., Alabama (in Museum National d'Histoire Naturelle, Paris). Jeannel 1936: 93; 1949: 103.

A small, slender, troglobitic species with the 3rd antennal segment longer than the 2nd, the transverse strigation of the pronotal disc rather superficial and irregular. Known from the type locality, in Jackson County; from Cathedral Caverns and Guffey Cave, Marshall County; and from Twin Caves, near Brownsboro, Pitts Sinkhole, at the head of Big Cove, and Cave Spring Cave, near Berkeley, all in Madison County, Alabama. Jeannel (r949) described P. v. jonesi from Pitts Sinkhole and $P$. v. longicornis from Cave Spring Cave. I have not seen enough Madison County material to comment on the validity of these subspecies. $P$. $v$. longicornis is known from a single male. The few specimens from Twin Caves are doubtfully assignable to $P$. v. jonesi. 


\section{Ptomaphagus (Adelops) loedingi Hatch}

Adelops lödingi Hatch 1953: 209, pl. 15, fig. 19; type: Shelta Cave, Huntsville, Madison Co., Alabama (U.S. Nat. Mus. \# 43763). Ptomaphagus (Adelops) lödingi: Jeannel 1936: $93 ; 1949: 104$.

A large troglobitic species characterized by the 3 rd antennal segment being distinctly longer than the 2nd; the 8th segment is subquadrate; the strigation is superficial but quite distinctly transverse. Known from the type locality and Barclay and Simmons Caves, Madison Co., Alabama; and from Stewart, Tumbling Rock, and Ivey Bottom Caves, Jackson Co., Alabama. The two populations of $P$. loedingi are apparently allopatric, one in Madison County and the other in Jackson County. They may eventually be proven to be subspecifically distinct, although I have seen only 7 specimens from Jackson County and am reluctant to make a diagnosis on this basis.

The original spelling of the trivial name is altered in accordance with Art. 32 (c) (i) of the International Code of Zoological Nomenclature, adopted by the XV International Congress of Zoology.

\section{Ptomaphagus (Adelops) fecundus $\mathrm{n}$. sp.}

Length 2.5-2.9 mm; width I.3-I.4 mm. Color dark brown, testaceous. Form elongate and slender, narrowing posteriorly. Eyes reduced to a very small, pale areola. Antenna slender, elongate, attaining the basal I/3 of elytra when laid back; segment I slightly thicker than segments II-V, which are subequal in diameter; segment I one and one-half times as long as II; segment II seven-eighths as long as III; IV-VII each about $4 / 5$ as long as III; VII subconical, I I/4 times as wide as VI at the apex and $5 / 8$ as wide as long; VIII subconical, I I/4 times wider than long; IX and $X$ each I/5 wider than long; $X I$ as wide as $X$ but $I / 3$ longer. Pronotum subequal in width to elytra, widest at the base, $2 / 3$ as long as wide; hind angles acuminate, less than right, base very shallowly emarginate between the hind angles; disc with transverse strigae finely impressed and distinct. Elytra elongate, tapering, $2 \mathrm{I} / 3$ times as long as pronotum; apices evenly rounded in the male, acuminate in the female with no external apical angle; strigae oblique to the suture; sutural angle narrow, its depth twice the distance between the apices. Aedeagus large and broad, as in $P$. loedingi. Described on holotype male and allotype female (both in American Museum of Natural History) and 94 paratypes, Caney Hollow Cave, Franklin Co., Tennessee, 9 May 1959 (T. C. Barr, Jr., leg.).

Abroad on the wet rock and mud floor among fragments of bat guano, the beetles were so numerous that it was difficult to traverse the cave without stepping on them. Caney Hollow Cave is located 
approximately 30 miles northeast of Huntsville, Alabama, at the margin of the Central Basin of Tennessee. The cave contains a perennial stream, is quite damp, and is inhabited by a large colony of bats (Myotis grisescens Howell), upon whose excrement the beetles feed.

$P$. fecundus is most closely allied to $P$. loedingi, from which it differs in having segment II of the antennae only $7 / 8$ as long as III, instead of $7 / 9$, and in having the elytral apices of the male rounded instead of subtruncate. P. hatchi inhabits the caves of eastern Franklin Co., Tennessee, at the base of the Cumberland Plateau. The Caney Hollow Cave is developed in Ordovician limestones immediately below the Chattanooga shale.

\section{Literature Cited}

Barr, Thomas C., JR.

1958. A new cave beetle of the genus Ptomaphagus (Catopidae) from DeKalb County, Tennessee. J. Tennessee Acad. Sci., $33(2): 170$ 171.

-1960a. Introduction (to Symposium: Speciation and raciation in cavernicoles). Am. Midl. Nat., 64(1):1-9.

- 1960b. The cavernicolous beetles of the subgenus Rhadine, genus Agonum (Coleoptera: Carabidae). Ibid., 64(1): 45-65.

-1962. The blind beetles of Mammoth Cave, Kentucky. Ibid., $68(2)$ : 278-284.

Hatch, Melville H.

1928. Coleopterorum catalogus, pars 95, Silphidae, II, pp. 63-244.

-1933. Studies on the Leptodiridae (Catopidae) with descriptions of new species. J. New York Ent. Soc., 41 (1/2): 187-239.

JEANNEL, RENÉ.

1933. Trois Adelops nouveaux de l'Amérique du Nord. Bull. Soc. Ent. France, 38: 251-253.

- 1936. Monographie des Catopidae. Mem. Mus. Nat. Hist. Nat., Paris, nouv. sér., 1, 433 pp., 1027 fig.

—1949. Les coléoptères cavernicoles de la région des Appalaches. Étude systématique. Notes Biospéologiques, 4, Publ. Mus. Nat. Hist. Nat., Paris, 12: 37-115.

Park, OrLando.

1960. Cavernicolous pselaphid beetles of the United States. Am. Midl. Nat., 64(1): 66-104.

Sanderson, Milton W.

1939. A new cave beetle of the subgenus Adelops from Oklahoma. J. Kansas Ent. Soc., $12(4): 121-122$.

SCHWARz, E. A.

1898. A new cave-inhabiting silphid. Proc. Ent. Soc. Waslington, 4: 57-58.

Tell kampf, Theodor.

1884. Beschreibung einiger neuer in der Mammuthöhle in Kentucky aufgefundener Gattungen von Gliederthieren. Arch. f. Naturgesch., $10: 312-322$. 

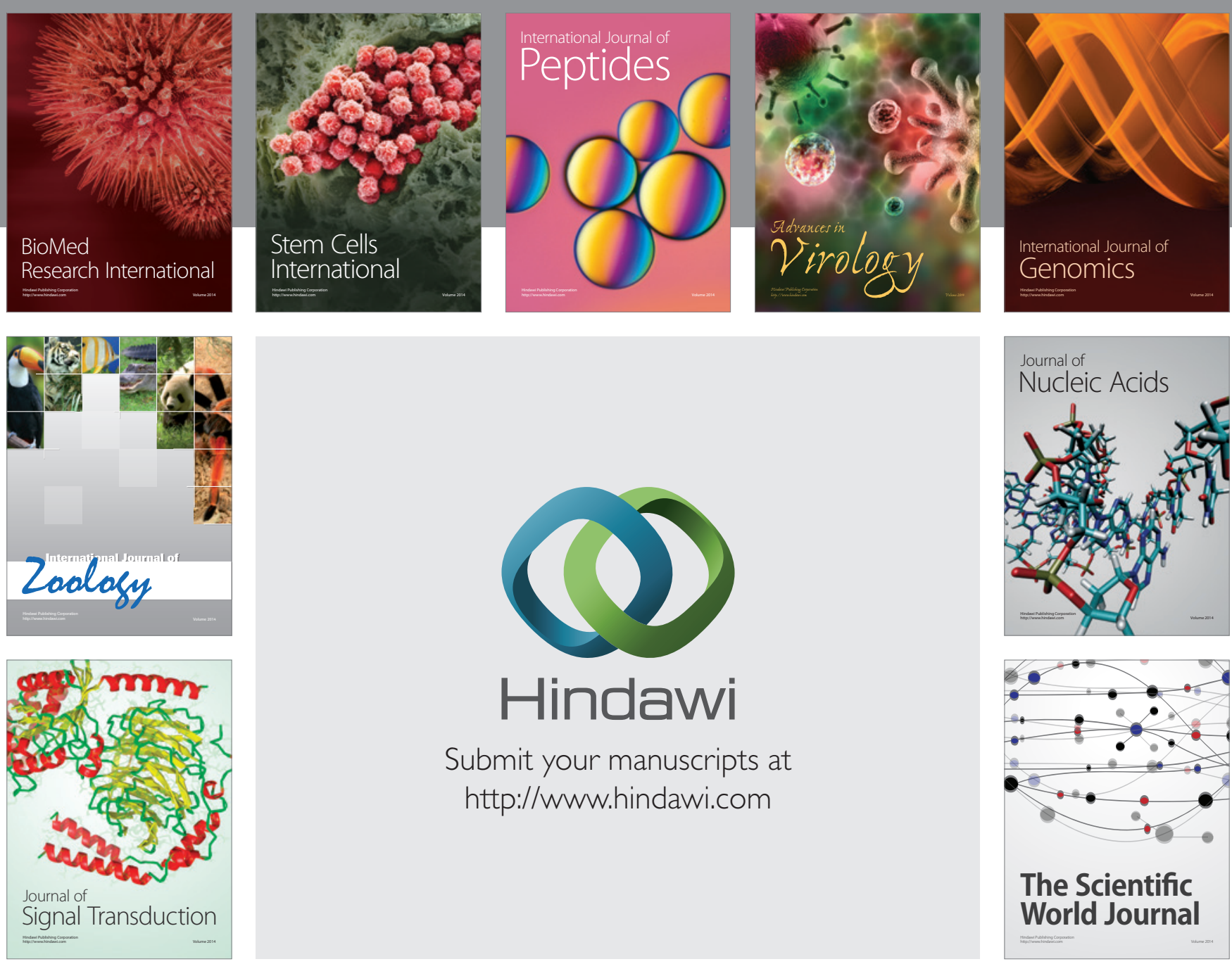

Submit your manuscripts at

http://www.hindawi.com
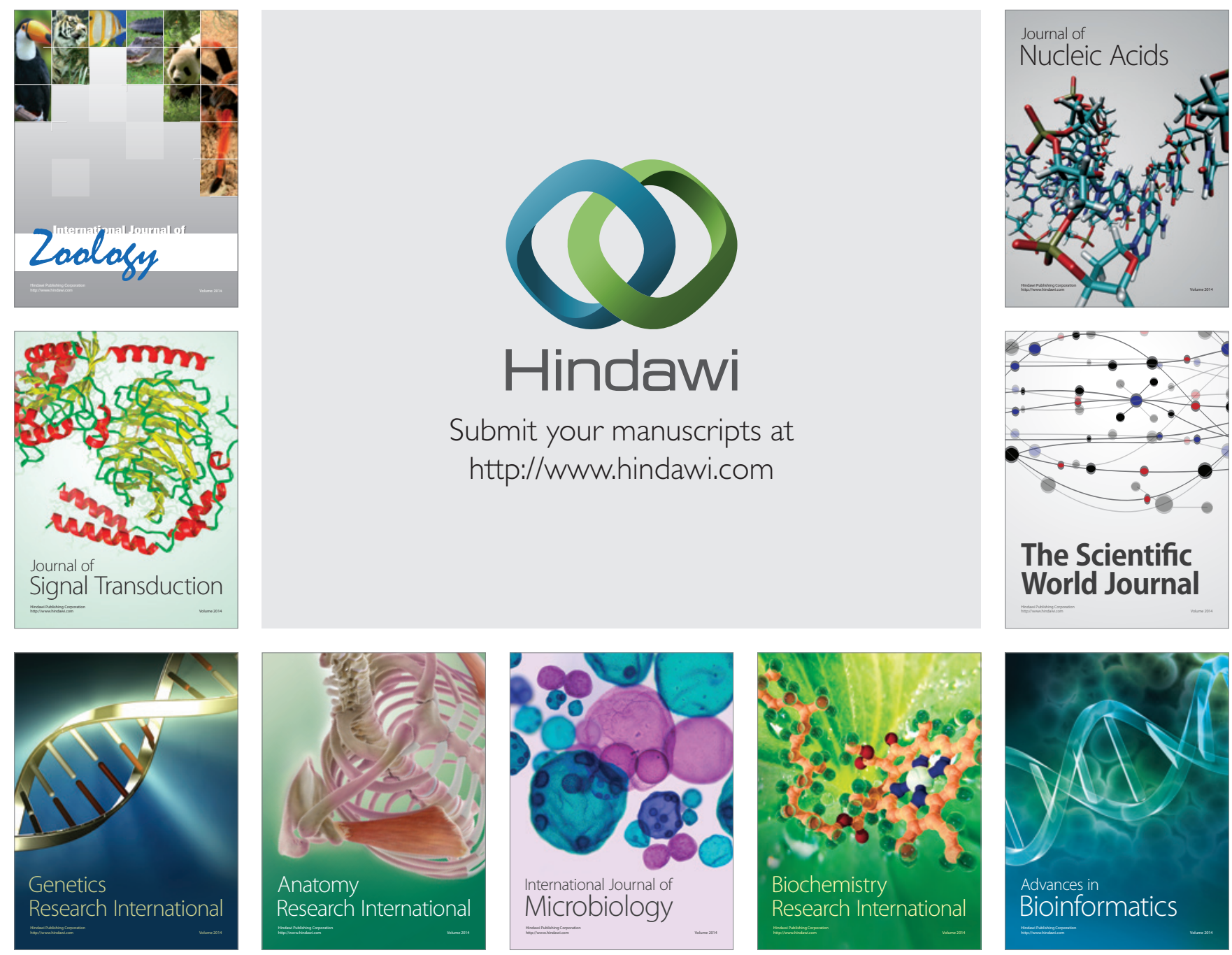

The Scientific World Journal
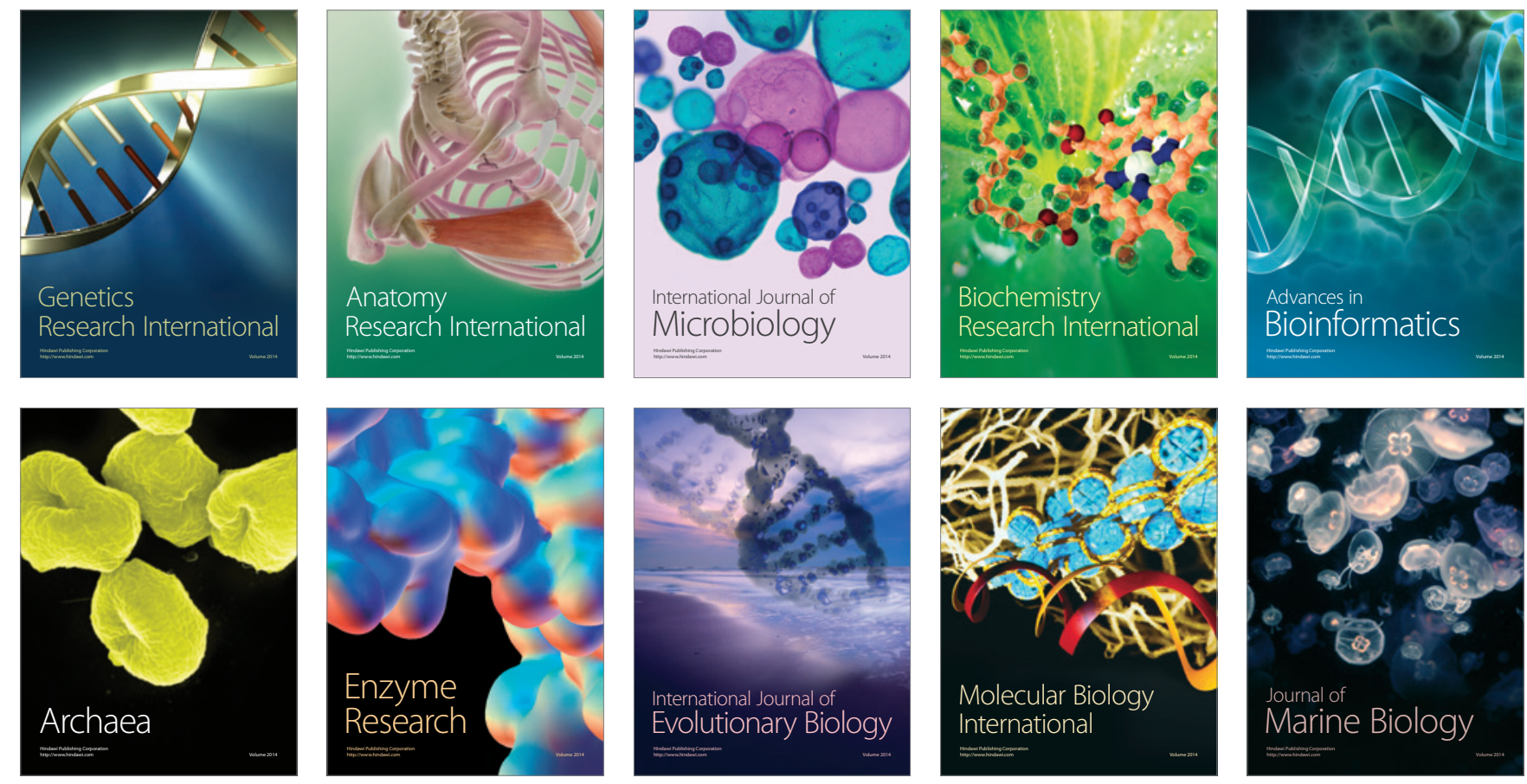